\title{
Molecular characterization of watermelon cultivars using microsatellite markers
}

\author{
Renata Natália CS Gama ${ }^{1}$; Carlos Antônio F Santos²; Rita de Cássia S Dias ${ }^{2}$; Flávio F Souza ${ }^{2}$ \\ ${ }^{1}$ UEFS, Progr. de pós-graduação em recursos genéticos vegetais. Av. Transnordestina s/n, Novo Horizonte, $44036-900$ Feira de Santana- \\ BA; renata.natalia@hotmail.com; ${ }^{2}$ Embrapa Semiárido, C. postal 23, 56302-970 Petrolina-PE; carlos-fernandes.santos@embrapa.br; rita. \\ dias@embrapa.br; flavio.souza@embrapa.br
}

\begin{abstract}
Allelic patterns and genetic similarity among 17 watermelon cultivars were established using microsatellite markers. For visualization of the genetic similarity, the dendrogram UPGMA (Unweighted Pair Group Method with Arithmetic Means) was generated by the similarity matrix of the Jacquard coefficient, based on 34 alleles of ten microsatellite loci. Total DNA was extracted by the CTAB 2x method and PCR (Polymerase Chain Reaction) products were analyzed in denaturing polyacrylamide $6 \%$ gels, stained with silver nitrate. The number of base pairs was estimated by the method of inverse mobility, based on known size product regression. Similarity ranged from 34 to $100 \%$, reflecting high genetic variability. Analyzed loci were not enough to distinguish all 17 watermelon cultivars. The pairs 'Sugar Baby' and 'Omaru Yamato', 'Charleston Gray' and 'Sunshade', 'Crimson Sweet' and 'Nova Crimson' presented $100 \%$ of similarity. In dendrogram two groups were observed at 0.42 similarity cut point, with Citrullus colocynthis, positioned as an out group. One watermelon group was formed predominantly by cultivars derived from 'Crimson' and another group was formed by cultivars of different types such as 'Sugar Baby', 'Charleston Gray' and 'Pérola'. Allele pattern and base pair (bp) estimates for the 34 alleles in the 10 microsatellite loci revealed in the present study are a first endeavor to use microsatellite markers in situations of cultivar protection for the watermelon agribusiness in Brazil. They can also be used in situations of commercial disputes regarding certification of the main watermelon cultivars used in the country.
\end{abstract}

Keywords: Citrullus lanatus, genetic divergence, SSR, plant variety protection.

\section{RESUMO}

Caracterização molecular de cultivares de melancia usando marcadores microssatélites

Foram estabelecidos padrões alélicos e distâncias genéticas para 17 cultivares de melancia utilizando marcadores microssatélites. Para a visualização da similaridade genética, utilizou-se o dendrograma UPGMA (Unweighted Pair Group Method with Arithmetic Mean) gerado da matriz de distâncias do coeficiente de Jaccard, com base em 34 alelos de dez locos microssatélites. O DNA total foi extraído pelo método de CTAB 2x e os produtos de PCR (Polymerase Chain Reaction) foram analisados em géis de poliacrilamida desnaturante $6 \%$ e corados com nitrato de prata. O número de pares de bases foi estimado pelo método da mobilidade inversa, com base na regressão de produtos de tamanho conhecido. A similaridade variou de 34 a $100 \%$, o que reflete a alta variabilidade genética das cultivares analisadas. Os locos analisados não foram suficientes para distinguir todas as 17 cultivares de melancia, e os pares 'Sugar Baby' e 'Omaru Yamato', 'Charleston Gray' e 'Sunshade', 'Crimson Sweet' e 'Nova Crimson' apresentaram $100 \%$ de similaridade. No dendrograma foram observados dois grupos entre as cultivares, no ponto de corte 0,42, com Citrullus colocynthis, posicionado fora desses grupos. Um grupo de melancia foi formado predominantemente por cultivares resultantes de 'Crimson' e outro grupo foi formado pelas cultivares de diferentes tipos, tais como 'Sugar Baby', 'Charleston Gray' e 'Pérola'. O padrão alélico e as estimativas em pares de base (pb) para os 34 alelos nos 10 locos microssatélites revelados no presente estudo são um primeiro esforço para usar marcadores microssatélites em situações de proteção de cultivares para o agronegócio da melancia no Brasil, podendo também ser utilizado em situações de disputas comerciais referentes à certificação ou não das principais cultivares de melancia usadas no país.

Palavras-chave: Citrullus lanatus, divergência genética, SSR, proteção de cultivares.

(Recebido para publicação em 17 de setembro de 2012; aceito em 17 de setembro de 2013) (Received on September 17, 2012; accepted on September 17, 2013)

$\mathrm{C}$ haracterizing germplasm diversity is a prerequisite for effective utilization of genetic resources. Genetic resources are defined as a fraction of biodiversity that is expected to have a current or potential use, including the landraces, improved varieties, advanced lines and native species (Giacometti, 1993). To carry on a watermelon breeding program it is really necessary to study the genetic variability contained in watermelon germplasm.

Morphological descriptors have been used by breeders to characterize, register and release new varieties. 
However, the limitations of this type of descriptor have created the need to find alternatives, one of which is the DNA descriptor based on the genotype of the individuals that have been highlighted, especially because of their potential to distinguish morphologically similar and genetically related genotypes. Molecular markers are alternatives to characterize germplasm and protect new cultivars without environmental interference (Milach, 1999).

Jarret et al. (1996) observed genetic variation among accessions of Citrullus lanatus var. lanatus, C. lanatus var. citroides and $C$. colocynthis, using seven simple sequence repeats (SSR) markers. Guerra-Sanz (2002) reported the identification of 18 SSR which detected polymorphism among the watermelon varieties, local races, C. colocynthis and interspecific hybrids. Joobeur et al. (2006) developed 36 SSR marker primers that detected polymorphism in eight watermelon accessions and four varieties. Kwon et al. (2010) assessed 63 pairs of SSR primers to discriminate 49 Korean and North American commercial watermelon varieties of which 30 presented polymorphism. However, according to these authors, there are many watermelon varieties that have not yet been differentiated by SSR markers.

Jufen et al. (2009) reported that three of 73 assessed SSR markers distinguished two watermelon hybrids from their parental lines, but 200 RAPD (Random Amplification of Polymorphic DNA) and 30 ISSR (InterSimple Sequence Repeat) primers could not differentiate them. The authors further identified two SSR markers that distinguished the two hybrids assessed, reinforcing the potential of this type of marker for studies on watermelon cultivar protection and commercial dispute arbitration.

Levi et al. (2009) applied 40 genetic SSR markers to watermelon accessions and cultivars and found greater diversity among the accessions than the cultivars. Lee et al. (2007) reported that applying 15 SSR was sufficient to differentiate 26 Korean watermelon cultivars, separating them into two groups, but no morphological and physiological associations were observed among the groups formed. In Brazil, the application of markers consists of among and within genetic divergence studies on accessions in germplasm banks, for example, conducted with RAPD markers by Capeloto et al. (2004) and Silva et al. (2006).

Although microsatellite markers are available for watermelon, a minimum number of this type of marker has not yet been proposed to help in cultivar protection and commercial dispute resolution. This et al. (2004) proposed a minimum of seven microsatellites to analyze grape cultivars and established reference alleles.

The objectives of the present study were to establish the allele patterns and estimate the genetic distances for 17 commercial watermelon cultivars based on microsatellite markers, generating a reference and support database for cultivar protection and possible commercial dispute arbitration and to guide watermelon breeding programs and genetic resources.

\section{MATERIAL AND METHODS}

Plant material - Seventeen watermelon cultivars, which are grown in Brazil, among them highly divergent cultivars and morphologically similar and genetically related cultivars, were analyzed and one Citrullus colocynthis accession was used as an out group species (Table 1). Seeds were obtained from the Watermelon Germplasm Bank (BGCIA), located at Embrapa Semiarid in the Brazilian Northeast. They were sown on polystyrene trays containing commercial plant substrate, based on vermiculite and plant ashes and kept in a greenhouse. The cultivars were grown at Petrolina, Pernambuco state, Brazil.

DNA extraction and quantification - DNA was extracted using the CTAB 2x (Doyle \& Doyle, 1990) method modified for 7,500 and $10,000 \mathrm{rpm}$, in the first and second centrifuges, respectively; $2 \%$ beta-mercaptoethanol and incubation at $60^{\circ} \mathrm{C}$ for $30 \mathrm{~min}$, for all the samples. After adding Tris-EDTA buffer, the solution was treated with RNAse to remove the co-extracted RNAs. The DNA was quantified and the integrity verified by electrophoresis in $0.8 \%$ agarose gel, stained with ethidium bromide and the band intensity of the extracted DNA was compared visually with the DNA Lambda that have known quantity, loaded in the same gel as the samples. Then, genomic DNA was diluted to $50 \mathrm{ng} / \mu \mathrm{L}$ and stored at $-20^{\circ} \mathrm{C}$.

DNA reaction amplification and resolution in polyacrylamide gels Thirty six microsatellite primers were used (Joobeur et al., 2006). First, primers pairs were assessed using four cultivars to select those with best polymorphic resolution in polyacrylamide gel. Polymerase Chain Reactions (PCR) were carried out following Joobeur et al. (2004) methodology, with some modifications for a final $12 \mu \mathrm{L}$ volume, containing $50 \mathrm{ng}$ DNA, $5 \mu \mathrm{M}$ of each primer, $0.1 \mathrm{mM}$ dNTP, $1.5 \mathrm{mM} \mathrm{MgCl}$, 1x PCR buffer and 0.75 units of the Taq DNA polymerase enzyme. The thermocycler Biometra, model-T1 Thermoblok was programmed for the amplifications as follows: a) a first cycle of $94^{\circ} \mathrm{C}$ for 2 minutes, followed by 30 cycles at $94^{\circ} \mathrm{C}$ for 15 seconds, at $56^{\circ} \mathrm{C}$ for 30 seconds and $72^{\circ} \mathrm{C}$ for 2 minutes and a final cycle at $72^{\circ} \mathrm{C}$ for 30 minutes.

A half of the volume of the denaturing 98\% formamide buffer (EDTA pH 8.010 $\mathrm{mM}, 1 \mathrm{mg} / \mathrm{mL}$ Xilene Cyanol and $1 \mathrm{mg} /$ $\mathrm{mL}$ Bromophenol blue) was added to the PCR product, followed by complete denaturation at $94^{\circ} \mathrm{C}$ for 5 minutes in a thermocycler and immediately placed on ice until the polyacrylamide gel was applied. The amplification products were separated in $6 \%$ polyacrylamide gel, prepared on a 60-well sandwichtype glass plate. A pre-run of 30 minutes at $40 \mathrm{~W}$ was carried out before applying the PCR samples. A $2.5 \mu \mathrm{L}$ aliquot was applied of the denatured PCR product in $6 \%$ polyacrylamide gel and the electrophoresis run lasted for approximately 3 hours, with constant 40 W power. The Ladder $50 \mathrm{bp}$ (Fermentas) molecular weight marker was loaded on the side edge of each gel. The gels were stained with silver nitrate following the procedure reported by Creste et al. (2001).

Microsatellite data notation and analysis - the loci that presented easily interpreted polymorphism were selected 
to genotype the 17 watermelon cultivars. The microsatellites were noted for allele presence (1) and absence (2) to construct a similarity matrix. The software NTSYSpc: Version 2.1 (Rohlf, 2000) was used to calculate the genetic similarity (Jaccard's coefficient), principal coordinate, and cluster analyses (Unweighted Paired Group Method Using Arithmetic Averages). The phenogram fit was assessed by the co-phenogram correlation, that is, the correlation between the real and graphically represented distances.

The main allele frequency, genotype number, simple size, allele number, gene diversity, heterozygosity and polymorphic information content (PIC) for the microsatellites were estimated using the Power Marker program (Liu \& Muse, 2005).

\section{RESULTS AND DISCUSSION}

Only 10 out of the 36 primer pairs presented easily interpreted polymorphic amplifications: MCPI-04, MCPI-05, MCPI-07, MCPI-11, MCPI-14, MCPI16, MCPI-21, MCPI-26, MCPI-33 and MCPI-39. Thirty-three alleles were detected on the 10 microsatellites analyzed, where the number of alleles per locus ranged from 2 to 6 , with an average of 3.3 alleles per microsatellite on the 17 watermelon cultivars and one C. colocynthis accession (Table 2). The number of microsatellite markers capable of detecting polymorphism in this study was much lower than that reported by Joobeur et al. (2006), who assessed the capacity to detect polymorphism of the same 36 primer pairs and reported that they were all polymorphic in eight watermelon accessions, including five $C$. lanatus var. lanatus accessions and three $C$. lanatus var. citroides accessions. This decrease in the number of all SSR markers in detecting polymorphism may have been due to the fact that in the present study these microsatellites were assessed for capacity to detect polymorphism in commercial watermelon cultivars that all belong to the $C$. lanatus var. lanatus subspecies.

The allele mean described was similar to the results reported by GuerraSanz (2002), Joobeur et al. (2006) and Kwon et al. (2010), who found 3.6, 2.8 and 3.9 alleles per locus, respectively. However, these results were below the mean reported by Jarret et al. (1996) of 4.7 alleles per locus, when assessing seven SSR markers in 33 watermelon accessions, including Citrullus lanatus var. lanatus, C. lantatus var. citroides and $C$. colocynthis.

PIC values, that reflected the allele diversity and frequency rates among the varieties, were not uniformly high for all the microsatellite loci tested. The PIC mean was 0.402 , being the greatest values observed in the MCPI-04 (0.597), MCPI-05 (0.583) and MCPI-16 (0.707) loci, and the lowest value in MCPI-14 (0.104) (Table 2). The mean heterozygosis was 0.189 and the greatest value was observed in MCPI-04 (1.0) and the lowest value (0) in MCPI-11, MCPI-21 and MCPI-26 (Table 2).

Table 1. Fruit trait and seed origin of 17 watermelon cultivars genotyped with 10 SSR loci (caracteres morfológicos e procedência das 17 cultivares genotipadas com dez marcadores SSR). Petrolina, Embrapa Semiárido, 2011.

\begin{tabular}{|c|c|c|c|c|}
\hline \multirow{2}{*}{ Cultivars } & \multicolumn{3}{|c|}{ Morphological characters } & \multirow{2}{*}{ Seed origin } \\
\hline & Fruit shape & Ground color & Flesh color & \\
\hline Minipool & Round & Light green with diffuse stripes & Red & Hazera \\
\hline Pérola & Broad elliptic & Light green with diffuse stripes & Red & $\mathrm{BGCIA}^{2}$ \\
\hline Smile & Round & Medium green with defined stripes & Red & BGCIA $^{2}$ \\
\hline BRS Soleil & Round & Medium green with defined stripes & Yellow & Embrapa \\
\hline BRS Kuarah & Round & Medium green with defined stripes & Yellow & Embrapa \\
\hline BRS Opara & Broad elliptic & Light green with defined stripes & Red & Embrapa \\
\hline Crimson Sweet & Broad elliptic & Light green with defined stripes & Red & Hortivale \\
\hline Crimson Select & Broad elliptic & Light green with defined stripes & Red & Hollar \\
\hline Nova Crimson & Broad elliptic & Light green with defined stripes & Red & Topsed \\
\hline Top Gun ${ }^{1}$ & Broad elliptic & Light green with defined stripes & Red & Syngenta \\
\hline Omaru Yamato & Round & Light green with diffuse stripes & Red & $\mathrm{BGCIA}^{2}$ \\
\hline Sugar Baby & Round & Dark green with indistinct veining & Red & $\mathrm{BGCIA}^{2}$ \\
\hline Fairfax & Oblong & Light green with defined stripes & Red & Feltrim \\
\hline Emperor Charleston Bonanza $^{1}$ & Elongated elliptic & Light green with diffuse stripes & Red & Isla seeds \\
\hline Charleston Gray & Elongated elliptic & Light green with diffuse stripes & Red & Isla seeds \\
\hline Peacock & Oblong & Dark green with indistinct veining & Red & BGCIA $^{2}$ \\
\hline Sunshade & Oblong & Light green with indistinct veining & Red & BGCIA $^{2}$ \\
\hline C. colocynthis & Round & Light green with defined stripes & White & $\mathrm{BGCIA}^{2}$ \\
\hline
\end{tabular}

${ }^{1}$ Hybrid; Source: Dias et al. (2010); Isla seeds (2011); Lane Agriculture Center (2009); ${ }^{2}$ Watermelon Germplasm Bank (BGCIA), located at Embrapa Semiarid in the Brazilian Northeast. 
Table 2. Estimated genetic parameters for 10 microsatellite loci in 18 watermelon genotypes (parâmetros genéticos estimados para 10 microssatélites em 18 genótipos de melancia). Petrolina, Embrapa Semiárido, 2011.

\begin{tabular}{lcccccc}
\hline SSR & MAF & GN & AN & GD & Het & PIC \\
\hline MCPI-04 & 0.472 & 4 & 6 & 0.654 & 1.000 & 0.597 \\
MCPI-05 & 0.444 & 5 & 4 & 0.650 & 0.056 & 0.583 \\
MCPI-07 & 0.694 & 3 & 3 & 0.440 & 0.056 & 0.365 \\
MCPI-11 & 0.722 & 4 & 4 & 0.444 & 0.000 & 0.409 \\
MCPI-14 & 0.944 & 2 & 3 & 0.106 & 0.056 & 0.104 \\
MCPI-16 & 0.361 & 5 & 4 & 0.748 & 0.500 & 0.707 \\
MCPI-21 & 0.611 & 2 & 2 & 0.475 & 0.000 & 0.362 \\
MCPI-26 & 0.889 & 2 & 2 & 0.198 & 0.000 & 0.178 \\
MCPI-33 & 0.750 & 3 & 2 & 0.375 & 0.056 & 0.305 \\
MCPI-39 & 0.528 & 4 & 3 & 0.523 & 0.167 & 0.412 \\
\hline Mean & 0.642 & 3.4 & 3.3 & 0.461 & 0.189 & 0.402 \\
\hline MAF
\end{tabular}

MAF (major allele frequency); GN (genotype number); AN (allele number); GD (gene diversity); Het (heterozygosity) and PIC (polymorphic information content).

Table 3. Allele pattern (in base pairs) estimated for 17 watermelon cultivars and one C. colocynthis accession, genotyped with 10 microsatellite markers (padrão alélico, em pares de bases, estimado para 17 cultivares e um acesso de C. colocynthis, genotipados com dez marcadores microssatélites). Petrolina, Embrapa Semiárido, 2011.

\begin{tabular}{|c|c|c|c|c|c|c|c|c|c|c|}
\hline \multirow{2}{*}{ Cultivars } & \multicolumn{10}{|c|}{ Loci MCPI } \\
\hline & 04 & 05 & 07 & 11 & 14 & 16 & 21 & 26 & 33 & 39 \\
\hline Minipool & $736 / 774$ & $556 / 556$ & $742 / 742$ & $738 / 738$ & $683 / 683$ & $810 / 810$ & $480 / 480$ & $640 / 640$ & $870 / 870$ & $965 / 965$ \\
\hline Pérola & 774/779 & $556 / 556$ & $742 / 742$ & $738 / 738$ & $683 / 683$ & $810 / 810$ & $475 / 475$ & $640 / 640$ & $856 / 856$ & $965 / 965$ \\
\hline Smile & 774/779 & $462 / 462$ & $623 / 623$ & $738 / 738$ & $683 / 683$ & $742 / 742$ & $475 / 475$ & $640 / 640$ & $856 / 856$ & $965 / 965$ \\
\hline BRS S & $736 / 774$ & $462 / 462$ & $623 / 623$ & $738 / 738$ & $683 / 683$ & $742 / 742$ & $475 / 475$ & $640 / 640$ & $870 / 870$ & /965 \\
\hline BRS Kuarah & $736 / 774$ & $556 / 556$ & $623 / 623$ & $738 / 738$ & $683 / 683$ & $810 / 810$ & $475 / 475$ & $640 / 640$ & $870 / 870$ & $965 / 965$ \\
\hline BRS Opara & $736 / 774$ & $462 / 462$ & $742 / 742$ & & $683 / 683$ & $742 / 742$ & $480 / 480$ & $577 / 577$ & $870 / 870$ & $942 / 942$ \\
\hline Crimson Sweet & $736 / 774$ & $462 / 462$ & $742 / 742$ & $831 / 831$ & $683 / 683$ & $742 / 742$ & $480 / 480$ & $640 / 640$ & $856 / 856$ & $942 / 942$ \\
\hline Crimson Select & $736 / 774$ & $462 / 462$ & $742 / 742$ & $831 / 831$ & $638 / 701$ & $742 / 742$ & $480 / 480$ & $640 / 640$ & $856 / 856$ & $942 / 942$ \\
\hline Nova Crimson & $736 / 774$ & $462 / 462$ & $742 / 742$ & $831 / 831$ & $683 / 683$ & $742 / 742$ & $480 / 480$ & $640 / 640$ & $856 / 856$ & $942 / 942$ \\
\hline Top Gun & 774/799 & $462 / 462$ & $742 / 742$ & $738 / 738$ & $683 / 683$ & $742 / 742$ & $480 / 480$ & $640 / 640$ & $856 / 856$ & $965 / 965$ \\
\hline Omaru Yamato & $736 / 774$ & $556 / 556$ & $623 / 623$ & 738/738 & $683 / 683$ & $810 / 810$ & $475 / 475$ & $640 / 640$ & $856 / 856$ & $965 / 965$ \\
\hline Sugar Baby & $736 / 774$ & $556 / 556$ & $623 / 623$ & $738 / 738$ & $683 / 683$ & $810 / 810$ & $475 / 475$ & $640 / 640$ & $856 / 856$ & $965 / 965$ \\
\hline Fairfax & & $462 / 462$ & $742 / 742$ & $728 / 728$ & $683 / 683$ & $742 / 742$ & $475 / 475$ & $640 / 640$ & $856 / 856$ & $942 / 942$ \\
\hline Emperor & $736 / 774$ & $556 / 507$ & $742 / 742$ & $738 / 738$ & $683 / 683$ & $810 / 835$ & $475 / 475$ & $640 / 640$ & $856 / 870$ & $942 / 965$ \\
\hline C. Gray & 774/799 & $507 / 507$ & $742 / 742$ & $738 / 738$ & $683 / 683$ & $835 / 835$ & $475 / 475$ & $640 / 640$ & $856 / 856$ & $942 / 942$ \\
\hline Peacock & $736 / 774$ & $556 / 556$ & $742 / 742$ & $738 / 738$ & $683 / 683$ & $810 / 810$ & $480 / 480$ & $577 / 577$ & $856 / 856$ & $942 / 965$ \\
\hline Sunshade & 774/799 & $507 / 507$ & $742 / 742$ & $738 / 738$ & $683 / 683$ & $835 / 835$ & $475 / 475$ & $640 / 640$ & $856 / 856$ & $942 / 942$ \\
\hline C. colocynthis & $671 / 703$ & $579 / 579$ & $722 / 742$ & 738/738 & $683 / 683$ & $787 / 787$ & $475 / 475$ & $640 / 640$ & $856 / 856$ & $965 / 1064$ \\
\hline
\end{tabular}

The most polymorphic SSR loci in the present study were also reported by Kwon et al. (2010) as some of the loci that presented greatest polymorphic information in the characterization of 49 Korean and North American varieties. The exception was MCPI-14, that was reported by these authors as one of the loci that presented the greatest PIC value but this was not observed in the present study, where MCPI-14 was the loci that presented the lowest PIC.

These results indicated that the most polymorphic SSR loci detected by Kwon et al. (2010) and in the present study were not necessarily the most informative for all the watermelon cultivars, whether Korean or North
American or from other countries, because of the variability found among the existing watermelon cultivars. The MCPI-11, MCPI-26 and MCPI-33 loci distinguished 'BRS Opara' from 'Crimson Sweet' and its derivatives ('Crimson Select', 'Nova Crimson' and 'Top Gun'). The MCPI-11 and MCPI39 loci distinguished the 'Top Gun' 


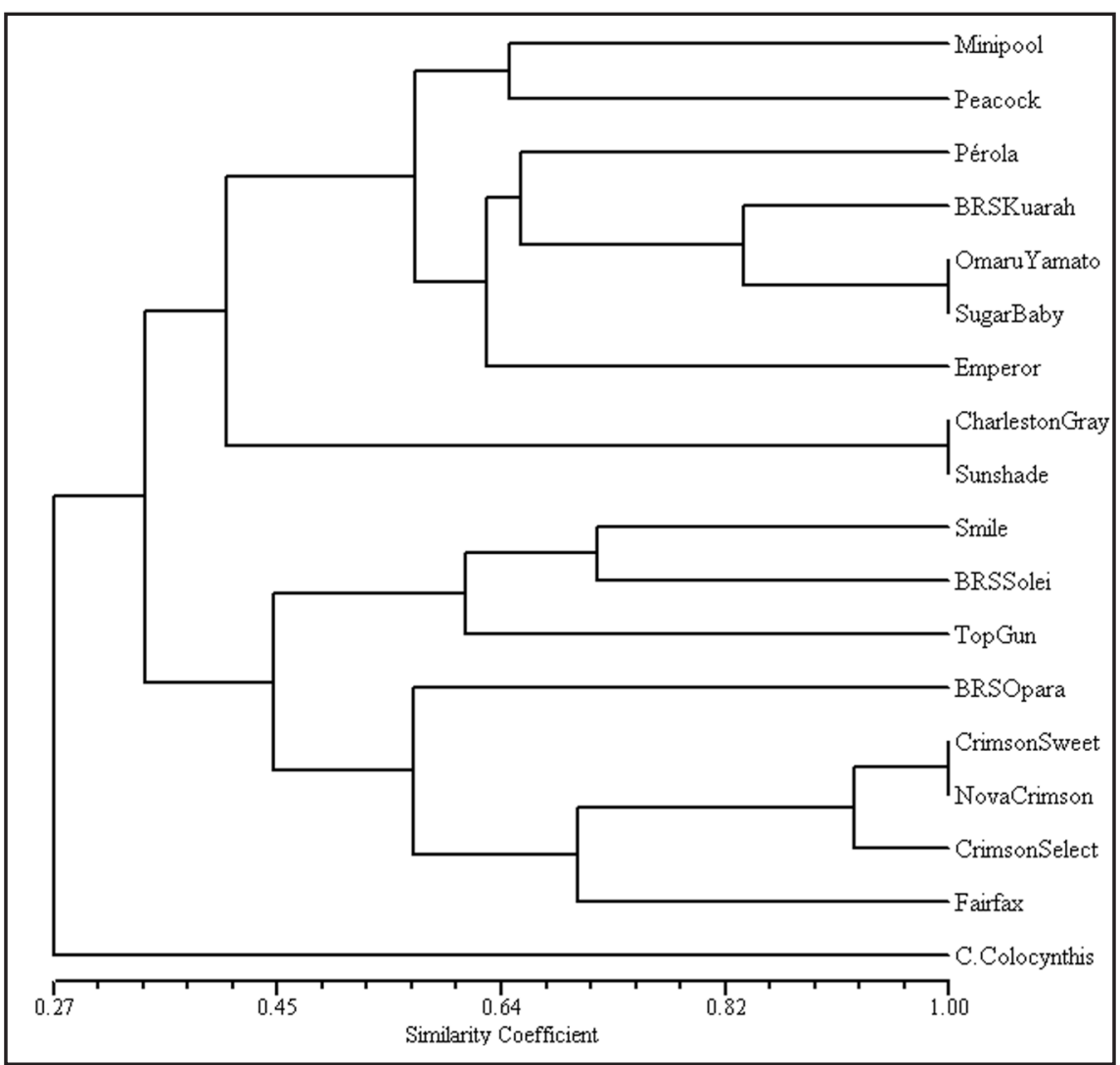

Figure 1. UPGMA dendrogram of the Jaccard similarity index of 17 watermelon cultivars and one $C$. colocynthis accession genotyped for 34 alleles of 10 microsatellite loci. Co-phenotype correlation $=0.86$ (dendrograma UPGMA do coeficiente de similaridade de Jaccard de 17 cultivares de melancia e um acesso $C$. colocynthis genotipados para 34 alelos de dez locos microssatélites. Correlação cofenética = 0,86). Petrolina, Embrapa Semiárido, 2011.

hybrid from 'Crimson Sweet' and its derivatives, as reported previously. The MCPI-14 loci distinguished 'Crimson Select' from 'Crimson Sweet'. However, none of the microsatellite loci analyzed could distinguish the 'Nova Crimson' from 'Crimson Sweet' (Table 3).

These results are very important, with great use for cultivar registration, because some microsatellite loci could distinguish the Crimson Sweet cultivar from it derivatives. It was emphasized once, that these cultivars are morphologically very similar and genetically related. Markers capable of distinguishing cultivars under these conditions are very important because they can be used to register new cultivars. As Brazilian consumers prefer striped skin patterns, like Crimson Sweet pattern, most breeding programs have used that genotype to obtain new cultivars. Thus, loci that can distinguish Crimson Sweet from its derivatives will be extremely useful during the registering process.

The allele size ranged from 462 bp on MCPI-05 to 1064 bp on MCPI39 (Table 3). The size of the alleles detected in the present study was different from the sizes reported by Kwon et al. (2010), who used the same microsatellite markers and reported allele size from $135 \mathrm{bp}$ on MCPI-42 to $298 \mathrm{bp}$ on MCPI-39. A hypothesis for this is that they may be different alleles because the microsatellite markers are multi-allelic. Laboratories that employ systems that use fluorescent initiators and automatic band recording can estimate different numbers of base pairs for the alleles identified in the present study, expecting, however, that the allelic pattern is maintained if the same protocol for the PCR reactions and amplifications is adopted.

The correlation between the cophenotypic value matrix and the similarity distance matrix was 0.86 indicating that the dendrogram (Figure 1) presented a good fit in the watermelon cultivars clustering with the 34 alleles of the 10 microsatellite loci analyzed. Three groups were observed at the cutting point of 0.42 similarity: group I: 'Minipool', 'Peacock', 'Pérola', 'BRS Kuarah', 'Omaru Yamato', 'Sugar Baby', 'Emperor Charleston Bonanza', 'Charleston Gray' and 'Sunshade'; group II: 'Smile', 'BRS Soleil', 'Top Gun', 'BRS Opara', 'Crimson Sweet', 'Nova Crimson', 'Crimson Select', and 'Fairfax', and group III: C. colocynthis (Figure 1). All the cultivars with diffuse or indistinct striped patterns were grouped in group 1 and the cultivars with defined striped pattern were placed in group 2.

Levi et al. (2000) characterized watermelon accessions with RAPD markers and reported the formation of three groups. The first group included commercial watermelon cultivars and the second, C. lanatus var. citroides accessions and in the third, C. colocynthis. Kwon et al. (2010) reported the formation of six groups when 49 Korean and American watermelon cultivars were characterized by microsatellites.

For Navot \& Zamir (1987), watermelon is a crop with narrow genetic base because of recurrent selection and continuous endogamy during 5000 years of cropping. This statement was confirmed by the low polymorphism found by these authors among watermelon cultivars and accessions based on izoenzymatic markers and by Levi et al. (2001), who analyzed the genetic variability of 46 American watermelon cultivars based on RAPD markers and found $92 \%$ and $99.6 \%$ genetic similarity among the cultivars. Che et al. (2003) reported similarity coefficient ranging from $82 \%$ to $99 \%$, in 28 watermelon cultivars from different origins, using AFLP markers.

The results of the present study, however, indicated high genetic variability among the cultivars analyzed because the similarity coefficient ranged from 34 to $100 \%$. It is important to emphasize that the cultivars 'Charleston Gray', 'Crimson Sweet', 'Peacock' 
and 'Sugar Baby' were among the cultivars analyzed by Levi et al. (2001) and in the present study. Kwon et al. (2010) also reported higher variability in 49 Korean and North American watermelon cultivars analyzed based on SSR markers where the similarity coefficient ranged from 13 to $100 \%$.

In spite the variability found in this work, the 34 alleles of the 10 SSR loci were not sufficient to separate all the 17 watermelon cultivars, suggesting that the varieties 'Sugar Baby' and 'Omaru Yamato', 'Charleston Gray' and 'Sunshade', 'Crimson Sweet' and 'Nova Crimson' were genetically identical for the loci analyzed. It is emphasized that these cultivars are morphologically very different. In some situations, SSR markers can present additional information when morphological descriptors are not enough to distinguish cultivars of a species that have a narrow genetic base (Priolli et al., 2002). In situations where it was not possible to distinguish accessions from a given species with a set of pre-established markers, Jakse et al. (2005) suggested that additional markers have to be used to reveal polymorphisms. According to Hamilton (2009), human forensic DNA profiles use 10-13 unlinked loci to estimate expected genotype frequencies. The microsatellite loci identified in the present study should be enough to allow identification of watermelon. However, additional primers, besides those tested in the present study, should be used in the futures studies.

Watermelon is an important crop in many developing countries and collaborative studies should be carried out in order to define a standard microsatellite set for identification and protection purposes, benefiting the entire watermelon community, especially plant breeders and farmers worldwide. Allele pattern and base pair (bp) estimates for the 34 alleles in the 10 microsatellite loci revealed in the present study are a first endeavor to use microsatellite markers in situations of cultivar protection for the watermelon agribusiness in Brazil.

\section{ACKNOWLEDGEMENTS}

The authors thank CAPES for the first author scholarship and Embrapa Semiarid for supporting the research activities.

\section{REFERENCES}

CAPELOTO A; UNEDA SHT; MAURO AO. 2004. Caracterização molecular entre e dentro de acessos de melancia através de RAPD - PCR. Revista Científica Eletrônica de Agronomia 3. Available in <http://www. revista.inf.br/agro05/ artigos/artigo01/ artigo01.htm> Accessed in May 6, 2011.

CHE KP; LIANG CY; WANG YG; JIN DM; WANG B. 2003. Genetic assessment of watermelon germplasm using the AFLP technique. HortScience 38: 81-84.

CRESTE S; TULMANN NETO A; FIGUEIRA A. 2001. Detection of single sequence repeat polymorphisms in denaturing polyacrylamide sequencing gels by silver staining. Plant Molecular Biology Reporter 19: 299-306.

DIAS RCS; BARBOSA GS; SOUZA FF; QUEIRÓZ MA; RESENDE GM; COSTAND. 2010. Cultivares. In: DIAS RCS; RESENDE GM; COSTAND (ed). Sistema de produção de melancia. Petrolina: Embrapa Semiárido, 2010. (Embrapa Semiárido. Sistemas de Produção, 6). Available in: <http://sistemasdeproducao. cnptia.embrapa.br/FontesHTML/Melancia/ SistemaProducaoMelancia/cultivares.htm> Accessed in May 6, 2011

DOYLE JJ; DOYLE JL. 1990. Isolation of plant DNA from fresh tissue. Focus 12: 13-15.

GIACOMETTI DC. 1993. Recursos genéticos de fruteiras nativas do Brasil. In: Simpósio nacional de fruteiras nativas, 1992, Cruz das Almas. Anais... Cruz das Almas: Embrapa CNPMF, p. 13-27.

GUERRA-SANZ JM. 2002. Citrullus simple sequence repeats markers from sequence databases. Molecular Ecology Notes 2: 223225.

HAMILTON MB. 2009. Population Genetics. Wiley-Blackwell, Chichester, West Sussex. pp. 22.

ISLA SEMENTES. Hibrido Emperor Charleston Bonanza. 2011. Available in $<\mathrm{http} / / \mathrm{www}$.isla. com.br/cgi-bin/detalhe.cgi?id=164 $>$ Accessed in May 6, 2011.

JAKSE J; MARTIN W; MCCALLUM J; HAVEY MJ. 2005. Single nucleotide polymorphisms, indels, and simple sequence repeats for onion cultivar identification. Journal of the American Society for Horticultural Science 130: 912-917.

JARRET RL; MERRICK LC; HOLMS T; EVANS J; ARADHYA MK. 1996. Simple sequence repeats in watermelon (Citrullus lanatus (Thunb) Matsum. \& Nakai). Genome 40: 433-441.

JOOBEUR T; GUSMINI G; ZHANG A; LEVI A; XU Y; WEHNNER TC; OLIVER M; DEAN RA. 2006. Construction of a watermelon BAC library and identification of SSRs anchored to melon or Arabidopsis genomes. Theoretical and Applied Genetics 112: 1553-562.

JOOBEUR T; KING JJ; NOLIN SJ; THOMAS CE; DEAN RA. 2004. The Fusarium resistance locus From-2 of melon contains a single resistance gene with complex features. The Plant Journal 39: 283-297.
JUFEN L; LING X; GUOBIN M. 2009. Identification of watermelon hybrid purity by molecular markers. Acta Agriculturae Shanghai 25: 72-75.

KWON YS; OH YH; YI SI; KIM HY; AN JM; YANG SG; OK SH; SHIM JS. 2010. Informative SSR markers for commercial variety discrimination in watermelon (Citrullus lanatus). Genes \& Genomics 32: 115-122.

LANE-AG CENTER. 2009. Watermelon cultivars. Available in <http://www.laneag. org/wmworld/Cultivars/cultivars.htm $>$ Accessed in May 6, 2011.

LEE HJ; CHO HJ; LEE KA; LEE MS; SHIN YS; HARN CH; YANG SG; NAHM SH. 2007. Development of sequence-based DNA markers for evaluation of phylogenetic relationships in Korean watermelon varieties. Journal of Crop Science Biotechnology 10: 98-105.

LEVIA; THOMAS CE; KEINATHAP; WEHNER TC. 2000. Estimation of genetic diversity among Citrullus accessions using RAPD markers. Acta Horticulturae 510: 385-390.

LEVI A; THOMAS CE; KEINATH AP; WEHNER TC. 2001. Genetic diversity among watermelon (Citrullus lanatus and Citrullus colocynthis) accessions. Genetic Resources and Crop Evolution 48: 559-566.

LEVIA; WECHTER P; DAVIS A. 2009. EST-PCR markers representing watermelon fruit genes are polymorphic among watermelon heirloom cultivars sharing a narrow genetic base. Plant Genetic Resources: Characterization and Utilization 7: 16-32.

LIU K; MUSE SV. 2005. Power Marker: an integrated analysis environment for genetic marker analysis. Bioinformatics 21: 21282129.

MILACH SCK. 1999. Marcadores moleculares nos recursos genéticos e no melhoramento de plantas. In: Queiróz MA; GOEDERT CO; RAMOS SRR (ed). Recursos genéticos e melhoramento de plantas para o Nordeste brasileiro. Petrolina: Embrapa Semiárido; Brasília-DF: Embrapa Recursos Genéticos e Biotecnologia. Available in $<\mathrm{http}: / / \mathrm{www}$. cpatsa.embrapa.br:8080/catalogo/ livrorg/ index.html $>$ Accessed in May 2, 2011.

NAVOT N; ZAMIR D. 1987. Isozyme and seed protein phylogeny of the genus Citrullus (Cucurbitaceae). Plant Systematics and Evolution 156: 61-67.

PRIOLLI RHG; MENDES-JUNIOR CT; ARANTES NE; CONTEL EPB. 2002. Characterization of Brazilian soybean cultivars using microsatellite markers. Genetics and Molecular Biology 25: 185-193.

ROHLF FJ. 2000. NTSYSpc numerical taxonomy and multivariate analysis system, version $2.10 \mathrm{~m}$. Setauket: Exeter Software.

SILVA ML; QUEIRÓZ MA; FERREIRA MAJF; BUSO GSC. 2006. Caracterização morfológica e molecular de acessos de melancia. Horticultura Brasileira 24: 405-409.

THIS P; JUNG A; BOCACCI P; BORREGO J; BOTTA R; CONSTANTINI L. 2004. Development of a standard set of microsatellite reference alleles for identification of grape cultivars. Theoretical and Applied Genetics 109: 1448-1458. 